\title{
Disseminated neoplasia in cockles Cerastoderma edule: ultrastructural characterisation and effects on haemolymph cell parameters
}

\author{
Seila Díaz ${ }^{1}$, Tristan Renault ${ }^{2}$, Antonio Villalba ${ }^{1}$, María Jesús Carballal $^{1, *}$ \\ ${ }^{1}$ Centro de Investigacións Mariñas, Consellería do Mar, Xunta de Galicia, 36620 Vilanova de Arousa, Spain \\ ${ }^{2}$ Institut Français de Recherche pour l'Exploitation de la Mer (IFREMER), Laboratoire de Génétique et Pathologie, \\ Ronce les Bains, 17390 La Tremblade, France
}

\begin{abstract}
Disseminated neoplasia (DN) has been detected in cockles from various beds in Galicia (NW Spain). A study was performed to characterise cockle neoplastic cell ultrastructure and to evaluate the effect of this disease at different severity stages on various haemolymph cell parameters. Examination of cockle neoplastic cells with transmission electron microscopy (TEM) showed round shapes and a lack of pseudopods, a high nucleus:cytoplasm diameter ratio, Golgi complexes, abundant mitochondria, ribosomes, and numerous endoplasmic reticulum tubes and electron-lucent vesicles. Various haemolymph cell parameters (cell mortality, non-specific esterase and lysosome biovolume, reactive oxygen intermediates [ROI] production, phagocytosis ability, intracellular $\mathrm{Ca}^{2+}$ and actin levels) were compared between DN severity categories by flow cytometry; haemocyte mortality, non-specific esterase activities and lysosome biovolume were found to be higher with increasing DN severity. The phagocytic ability of neoplastic cells was sharply reduced with regard to haemocytes. The cytoplasmic-free $\mathrm{Ca}^{2+}$ level was higher and actin content lower in haemolymph cells of diseased cockles compared to unaffected ones. A significant increase in ROI production was detected in later stages of disease progression.
\end{abstract}

KEY WORDS: Disseminated neoplasia $\cdot$ Cerastoderma edule $\cdot$ Non-specific esterases $\cdot$ Lysosome Respiratory burst $\cdot$ Phagocytosis $\cdot$ Cytoplasmic free $\mathrm{Ca}^{2+} \cdot$ Actin

\section{INTRODUCTION}

One of the primary roles of haemocytes in bivalve molluscs is defence. Phagocytosis of foreign particles by haemocytes is an important process of the cellular defence system, and different phases can be observed through the process: recognition, adhesion, ingestion, destruction and elimination of foreign cells or particles (Yakovleva et al. 2001, Tiscar \& Mosca 2004, Goedken et al. 2005). Lysosomal enzymes and cytotoxic molecules produced by haemocytes contribute to the destruction of phagocytosed pathogenic organisms (Cheng 1981).

Disseminated neoplasia (DN) is an invasive disease in which the haemocytes are progressively replaced with neoplastic cells. DN has been reported for 15 species of marine bivalves throughout the world (Peters 1988, Elston et al. 1992), cockles Cerastoderma edule among them. The ontogeny of DN in bivalve molluscs is not well understood, although many authors favour a haemopoietic origin (Barber 2004). Neoplastic cells are characterised by their rounded shape, inability to spread out by means of pseudopodia and filipodia, and absence of cell aggregation (Balouet \& Poder 1985). Regression of the disease may occur, but only in the initial stages (Elston et al. 1988). Thus, the loss of haemocytes could leave the host immunity compromised, and the individuals affected by DN could die as result of secondary infections. High mortality has been associated with DN (Barber 2004). DN has been de- 
tected in cockles from various beds in Galicia (NW Spain) and its association with cockle mortality was suggested in natural beds (Carballal et al. 2001, Villalba et al. 2001). Significantly higher mortality of DNaffected cockles than of unaffected ones has been confirmed in laboratory tanks (S. Díaz unpubl. data).

Various studies have shown the loss of phagocytosis ability of neoplastic cells in comparison with normal haemocytes in Mytilus trossulus (Kent et al. 1989, Noël 1992), M. edulis (Galimany \& Sunila 2008) and Mya arenaria (Beckmann et al. 1992, Potts 1993). Analyses by light microscopy showed failures in adhesion and spreading on glass slides of neoplastic cells in $M$. edulis (Elston et al. 1988). Loss of adhesion ability could be the result of an alteration of the cell surface proteins. Normal haemocytes of $M$. arenaria express a $130 \mathrm{KDa}$ protein recognised by murine monoclonal antibody MAB 2A4 that is not detected in neoplastic cells (Miosky et al. 1989), which may be related to adherence (White et al. 1993). Differences in adherence and phagocytic behaviour between haemocytes and neoplastic cells are related to altered cytoskeletal structure. Significant differences in the cytoskeletal architecture and quantity of actin filaments were found between haemocytes and abnormal cells of $M$. arenaria (Moore et al. 1992).

Lysosomal enzymes and reactive oxygen intermediates (ROIs) are immune factors used by haemocytes during phagocytosis to destroy microorganisms (Cheng 1981). Hydrolytic enzymes were detected in neoplastic cells of Mytilus edulis (Lowe \& Moore 1978) in spite of their reduced phagocytosis ability; qualitative and quantitative increments of lytic enzyme activity were found in neoplastic cells of Mya arenaria (Beckmann et al. 1992). Nevertheless, no significant differences were found for ROI production between neoplastic cells and normal haemocytes of $M$. edulis (Galimany \& Sunila 2008).

Flow cytometry is a versatile technique applicable to both morphological and functional studies of suspended particles. Flow cytometry makes it possible to analyse different parameters simultaneously in a large number of cells in a short time, thus improving the efficiency and capacity of more traditional immunological methods (Fisher \& Ford 1988). Flow cytometry has been used to analyse size, organelle contents, viability, phagocytosis capacity, enzyme activities and ROI production of haemocytes in various bivalve mollusc species (Gagnaire et al. 2004, 2006, 2008, Samain et al. 2007, Morga et al. 2009)

The aim of the present work was to characterise the ultrastructure of neoplastic cells of cockles through transmission electron microscopy (TEM) and to evaluate the effect of disease at different severity stages on various haemolymph cell parameters using flow cytometry. The cell parameters studied were cell mortality, non-specific esterase activities, lysosome biovolume, ROI production, phagocytosis ability, and intracellular $\mathrm{Ca}^{2+}$ and actin levels.

\section{MATERIALS AND METHODS}

Cockle collection and diagnosis. Cockles Cerastoderma edule were collected from a natural intertidal bed affected by DN in Ría de Arousa (Galicia, NW Spain) in April 2007 and transported to the laboratory in the Centro de Investigacións Mariñas, Vilanova de Arousa, Spain. Each cockle was notched through the shell margin close to the posterior adductor muscle, and a small quantity (ca. $100 \mu \mathrm{l}$ ) of haemolymph was collected from the posterior adductor muscle using a $2 \mathrm{ml}$ syringe with a 21 gauge needle. The haemolymph was diluted 1:2 in cold Alsever's anti-aggregant solution and used to produce a cell monolayer on a slide by cytocentrifugation $\left(92 \times g, 5 \mathrm{~min}, 4^{\circ} \mathrm{C}\right)$. The monolayer was fixed, stained with Hemacolor ${ }^{\circledR}$ (Merck) kit and examined with light microscopy for DN diagnosis. The cockles were ranked according to a scale of disease severity: unaffected (N0), low severity (N1) in which individuals showed proportions of neoplastic cells lower than $15 \%$ in the haemolymph cell monolayers, moderate severity (N2) in which proportions ranged from 15 to $75 \%$, and high severity (N3) in which proportions were higher than $75 \%$ (Díaz et al. 2010). The diagnosed cockles were kept in a tank with running sea water for $2 d_{i} 3$ of those with high severity DN were used for TEM examination and the remaining ones were transported to the Laboratoire de Pathologie et Génétique in La Tremblade, France in a refrigerated container for flow cytrometry analyses.

The diameters of cells corresponding to each cell type that was recognised in haemolymph cell monolayers from healthy and DN-affected cockles were measured ( $\mathrm{n}=100$ cells of each type) to determine the mean $( \pm \mathrm{SD})$ size of each cell type.

TEM preparation. Haemolymph was collected from 3 N3 cockles. The haemolymph was diluted 1:1 in fixative solution $(2.5 \%$ glutaraldehyde in sodium cacodylate $0.2 \mathrm{M}$ with sucrose) for $30 \mathrm{~min}$. Diluted haemolymph was centrifuged $(750 \times g, 10 \mathrm{~min})$ and the pellet was washed in $0.2 \mathrm{M}$ sodium cacodylate buffer with $7 \%$ sucrose for $2 \mathrm{~h}$ at $4^{\circ} \mathrm{C}$. Cells were pre-embedded in $1.5 \%$ agarose at $50^{\circ} \mathrm{C}$ and centrifuged $(1700 \times g$, $5 \mathrm{~min})$. Small pieces were cut, post-fixed in $1 \%$ osmium tetroxide in sodium cacodylate solution and embedded in Epon resin. Ultrathin sections (50 to $70 \mathrm{~nm}$ ) were stained with uranyl acetate and lead citrate and examined in a JEM-1010 transmission electron microscope (JEOL Korea). 
Flow cytometry analyses. Once the cockles arrived at the Laboratoire de Pathologie et Génétique, they were kept in a tank with running sea water for $24 \mathrm{~h}$. Haemolymph was collected again from survivor cockles. Haemolymph was pooled according to severity classes using haemolymph from 4 cockles respectively for each pool. A total of 3 pools from N0 cockles, 3 pools from N1 cockles, and 3 pools from N2 + N3 cockles was produced. The haemolymph of $3 \mathrm{~N} 2$ cockles and 1 N3 cockle was mixed in each N2 + N3 pool because only 3 N3 cockles survived. The tubes with the haemolymph pools were set in a bed of crushed ice to avoid cell aggregation. After pooling, the haemolymph was filtered through a $60 \mu \mathrm{m}$ mesh sieve to avoid blocking the flow cytometer capillary with unexpected large debris. Haemolymph cells were counted in a Malassez haemocytometer and the concentration was adjusted to $10^{6}$ cells ml ${ }^{-1}$ with artificial seawater (ASW: $23.4 \mathrm{~g} \mathrm{NaCl} 1.5 \mathrm{~g} \mathrm{KCl} 1.2 \mathrm{~g} \mathrm{MgSO}_{4} \cdot 4 \mathrm{H}_{2} \mathrm{O}, 0.15 \mathrm{~g}$ $\mathrm{CaCl}_{2} \cdot 2 \mathrm{H}_{2} \mathrm{O}, 0.15 \mathrm{~g} \mathrm{CaCl}_{2}$ anhydrous, $\mathrm{H}_{2} \mathrm{O}$ qsp $1 \mathrm{~L}$ ).

The diluted haemolymph pools were analysed with flow cytometry to evaluate the following variables: cell mortality, non-specific esterase activity, lysosome biovolume, phagocytic activity, ROI production, intracytoplasmic $\mathrm{Ca}^{2+}$ content and actin content. Haemolymph cells were examined with an EPICS XL 4 flow cytometer (Beckman Coulter) and the results were analysed with the EXPO XL 4 software. Results were depicted as cell cytograms and reported in log scale fluorescence levels, indicating forward scatter values (FSC), side scatter values (SSC) and the fluorescence intensity in the channel (wave length) corresponding to the marker used for each immune parameter. FSC correlates with the cell volume and SSC depends on the inner complexity of the cell (i.e. the shape of the nucleus, the amount and type of cytoplasmic organelles or the membrane roughness). Non-specific esterases, lysosome biovolume, phagocytic activity, intracytoplasmic $\mathrm{Ca}^{2+}$ content, ROI production and actin content were measured using green fluorescence, and cell mortality was evaluated with red fluorescence. Three measurements were carried out for every haemolymph pool, counting 3000 events for each measurement. For cell mortality and phagocytosis capacity, the percentage of dead cells and phagocytic cells, respectively, were calculated. For non-specific esterase activity, ROI production, lysosome detection, cytoplasmic-free $\mathrm{Ca}^{2+}$ and actin contents gates were defined on the cytograms to distinguish either 2 or 3 different cell populations according to fluorescence intensity.

Cell mortality: Percentages of dead cells were assessed using propidium iodide, which permeates only through the membrane of dead cells and stains nucleic acids. Diluted haemolymph $(200 \mu \mathrm{l})$ was incubated with $10 \mu \mathrm{l}$ of a solution containing $1.0 \mathrm{~g} \mathrm{l}^{-1}$ of pro- pidium iodide (Molecular Probes) for $30 \mathrm{~min}$ at $4{ }^{\circ} \mathrm{C}$ (Xue et al. 2001).

Non-specific esterases: The content of non-specific esterases was measured with fluorescein diacetate (FDA, Interchim), a non-fluorescent molecule that can pass through cell membranes which is hydrolised by intracellular non-specific esterases, thus producing the fluorescent product fluorescein. Diluted haemolymph $(200 \mu \mathrm{l})$ was treated with $1 \mu \mathrm{l}$ of a solution containing $400 \mu_{\mathrm{mol} \mathrm{l}} \mathrm{l}^{-1}$ FDA (Gagnaire et al. 2006).

Lysosome quantification: The lysosome biovolume in cells was determined using a commercial kit (LysoTracker $^{\circledR}$ Green DND-26, Molecular Probes). The LysoTracker probe actually accumulates in intra-cytoplasmic acid compartments in live cells, which are mainly lysosomes (Donaghy et al. 2010). Diluted haemolymph $(200 \mu \mathrm{l})$ was incubated with $1 \mu \mathrm{l}$ of LysoTracker ${ }^{\circledR}$ at room temperature for $2 \mathrm{~h}$ in the dark (Gagnaire et al. 2006).

Reactive oxygen intermediates: The respiratory burst was measured using 2'-7' -dichlorofluorescein-diacetate (DCFH-DA, Molecular Probes), a non-fluorescent compound that is oxidised to the fluorescent $2{ }^{\prime}-7^{\prime}-$ dichlorofluorescein (DCF) in presence of hydrogen peroxide. Diluted haemolymph $(200 \mu \mathrm{l})$ was treated with $2 \mu \mathrm{l}$ of a solution containing $1 \mathrm{mM}$ DCFH-DA at room temperature for $30 \mathrm{~min}$ (Gagnaire et al. 2006).

Phagocytosis: Phagocytosis activity was measured by ingestion of fluorescent beads (Gagnaire et al. 2006). Diluted haemolymph $(200 \mu \mathrm{l})$ was incubated for $1 \mathrm{~h}$ in the dark at room temperature with $10 \mu$ of a 1:10 dilution of Fluorospheres ${ }^{\circledR}$ carboxylate-modified microspheres (1 $\mu \mathrm{m}$ diameter, Interchim) at a 200:1 beads:cells final ratio. The phagocytic activity was expressed as the percentage of cells that had ingested at least 3 beads.

Cytoplasmic-free $\mathbf{C a}^{2+}$ : The intracellular $\mathrm{Ca}^{2+}$ content was measured using Fluo-3-AM (Molecular Probes), a cell-permeable fluorescent indicator of intracellular $\mathrm{Ca}^{2+}$, because it is non-fluorescent until it is hydrolysed in the presence of $\mathrm{Ca}^{2+}$. Diluted haemolymph $(400 \mu \mathrm{l})$ was incubated with $1 \mu \mathrm{l}$ of a solution containing $10 \mu \mathrm{M}$ Fluo-3-AM for $1.5 \mathrm{~h}$ at room temperature (Aton et al. 2006).

Actin: The actin content was measured by phallotoxins (Alexa Fluor ${ }^{\circledR} 488$ conjugated phalloidin, Molecular Probes), which bind to actin without cross reaction with other cytoskeletal components. Cells were first fixed in $3.7 \%$ formaldehyde solution for $10 \mathrm{~min}$ at room temperature and were then treated for $4 \mathrm{~min}$ at room temperature with $0.1 \%$ Triton X-100. Pre-treated cells were then incubated for $30 \mathrm{~min}$ on ice with Alexa Fluor ${ }^{\circledR} 488$ phalloidin (Shi et al. 2003).

Statistical analysis. In the cases of non-specific esterase activity, lysosome quantification, ROI production, intracytoplasmic $\mathrm{Ca}^{2+}$ content and actin con- 
tent, comparisons of the distributions of haemolymph cells in different populations between disease severity categories were performed using contingency tables and $\chi^{2}$ tests, in which the cell populations were organised into columns and the disease severity categories into rows. However, the requirements for the performance of that test were not fulfilled in the cases of cell mortality and phagocytic ability. Thus the comparisons of the percentages of dead cells and phagocytosing cells between classes of disease severity were performed by ANOVA; those percentages were arcsine transformed to meet ANOVA requirements. Significance was concluded at $\mathrm{p} \leq 0.05$. The statistical analyses were performed using Minitab 15 software.

\section{RESULTS}

\section{Cell types in haemolymph cell monolayers}

Three cell types were classified into haemolymph cell monolayers according to morphological characteristics. Hyalinocytes were the smallest cell type (mean \pm SD: $12.9 \pm 2.9 \mu \mathrm{m}$ in diameter) and did not show cytoplasmic granules. Granulocytes showed cytoplasmic granules, were larger than hyalinocytes $(14.5 \pm 2.6 \mu \mathrm{m})$ and showed a low nucleus:cytoplasm diameter ratio. Neoplastic cells were the largest cell type (22.6 \pm $3.8 \mu \mathrm{m}$ ) and had a high nucleus:cytoplasm ratio and darker cytoplasm.

\section{TEM examination}

Neoplastic cells were larger than normal cockle haemocytes. They were round to oval-shaped in section, with a high nucleus:cytoplasm diameter ratio (Fig. 1A-C). No pseudopodia or similar structures were found. Nuclei were pleomorphic and usually lobed (Fig. 1A-D). One eccentric hypertrophied nucleolus was frequent (Fig. 1A,B), although 2 nucleoli were usually observed in histological sections. Dense fibrillar components were observed inside the nucleoli (Fig. 1A,B). The heterochromatin was scattered in small aggregates (Fig. 1D). The cytoplasm contained numerous organelles. Endoplasmic reticulum tubules extended from and around the nucleus (Fig. 1A-D,G). Golgi complexes, frequently more than one per cell section (Fig. 1E), were located close to the nucleus; they were composed of various abnormally large cisternae with an increased number of stacks and numerous vesicles of different shape and size (Fig. 1E,F). Ribosomes were not very abundant. Some were free in the cytosol and others were attached to membranes of the endoplasmic reticulum (Fig. 1G). Mitochondria were abundant, either alone or forming clusters (Fig. 1A,B). They had numerous dilated cristae of which some were large (Fig. 1H). Numerous electron-lucent vesicles of different size and shape were dispersed through the cytoplasm (Fig. 1A-H).

\section{Flow cytometry analysis}

\section{Cytometric identification of cell populations}

Flow cytometry allowed for the separation of haemocytes from neoplastic cells by distinctive morphological characteristics. The analysis based on cell size (FSC) and cell inner complexity (SSC) of the N0 cockles showed a heterogeneous population that corresponded to haemocytes (Fig. 2A). The cockles of the N2+N3 DN severity category clearly showed an extra homogenous cell population that involved larger, more complex cells (Fig. 2B), which agreed with light and electron microscopy characteristics of neoplastic cells. The N1 cockles showed cells of both populations but had fewer neoplastic cells than N2+N3 cockles.

\section{Cell mortality}

The maximum value of haemolymph cell mortality was $6.8 \%$. Categories with more severe DN had higher cell mortality. Haemocyte mortality was higher than that of neoplastic cells in every DN severity category and sharply increased in cockles of the N2 + N3 severity category (Fig. 3).

\section{Non-specific esterase activities}

Haemolymph cells were classified into 3 populations by their non-specific esterase activities, based on green fluorescence intensity. The first cell population showed low non-specific esterase activities (mean \pm SD; $5.65 \pm$ 0.30 fluorescence units) and corresponded to haemocytes of small size and low inner complexity, thus probably being hyalinocytes. The second cell population showed moderate non-specific esterase activities (39.55 \pm 3.29 fluorescence units) and corresponded to larger and more complex haemocytes, thus probably granulocytes, and the third cell population showed high nonspecific esterase activities (143.25 \pm 33.32 fluorescence units) and corresponded to the size and inner complexity of neoplastic cells. The percentage of cells with moderate non-specific esterase activities (probably mostly granulocytes) was lowest in N2+N3 cockles. The distribution of cells in populations according to the level of non-specific esterase activities was significantly associated with DN severity. Categories with more se- 

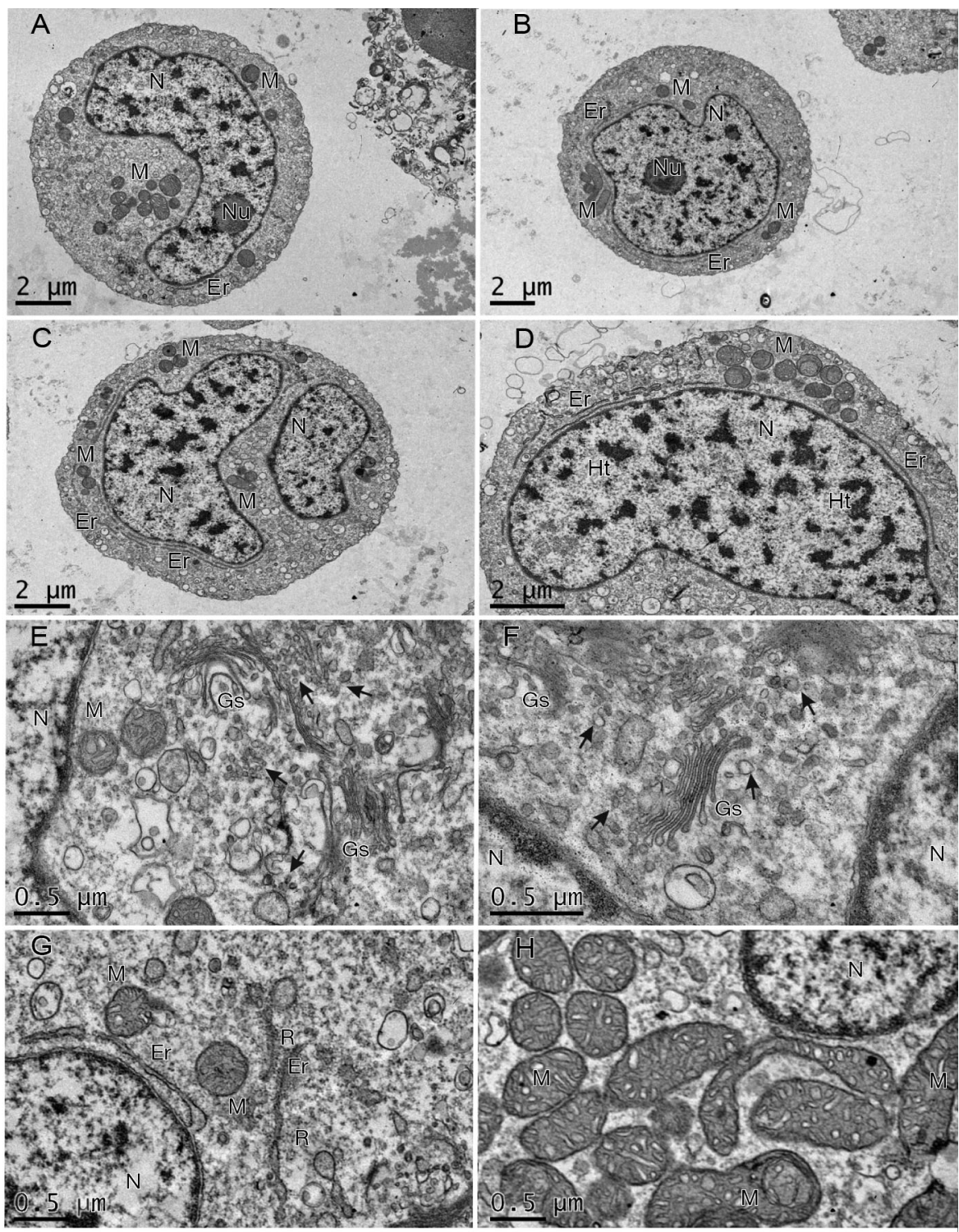

Fig. 1. Cerastoderma edule. Cockle neoplastic cells shown under TEM. (A-D) Neoplastic cells with round to oval shapes, enclosing pleomorphic nuclei with heterocromatin scattered in small aggregates, nucleoli containing dense fibrillar material, and (A, B) cytoplasm that contains abundant mitochondria and numerous vesicles and endoplasmic reticula. Scale bars $=2 \mu \mathrm{m}$. (E-G) Detailed views of cytoplasm in neoplastic cells showing $(\mathrm{E}, \mathrm{F})$ Golgi complexes with numerous Golgi stacks and Golgi vesicles (arrows) and $(\mathrm{G})$ endoplasmic reticula and free and reticulum-associated ribosomes. Scale bars $=0.5 \mu \mathrm{m}$. (H) Group of mitochondria with numerous, dilated cristae. Scale bar $=0.5 \mu \mathrm{m}$. Er: endoplasmic reticulum; Gs: Golgi stacks; Ht: heterocromatin; M: mitochondria; N: nucleus; Nu: nucleolus; R: ribosomes

vere DN had higher percentages of cells with high nonspecific esterase activities and lower percentages of cells with low and moderate non-specific esterase activities (Fig. 4).

\section{Lysosome quantification}

Haemolymph cells were classified into 3 populations based on lysosome quantification: a first cell population with low green fluorescent intensity $(4.69 \pm 0.21$ fluorescence units) that corresponded to haemocytes of small size and low inner complexity, thus probably hyalinocytes; a second cell population with moderate green fluorescence $(23.04 \pm 1.66$ fluorescence units $)$ that corresponded to larger and more complex haemocytes, thus probably granulocytes; and a third cell population with high green fluorescence (102.48 \pm 6.99 fluorescence units), most of them corresponding to the size and inner complexity of neoplastic cells. The percdentage of cells with moderate green fluorescence (probably mostly granulocytes) was lowest in $\mathrm{N} 2+\mathrm{N} 3$ 

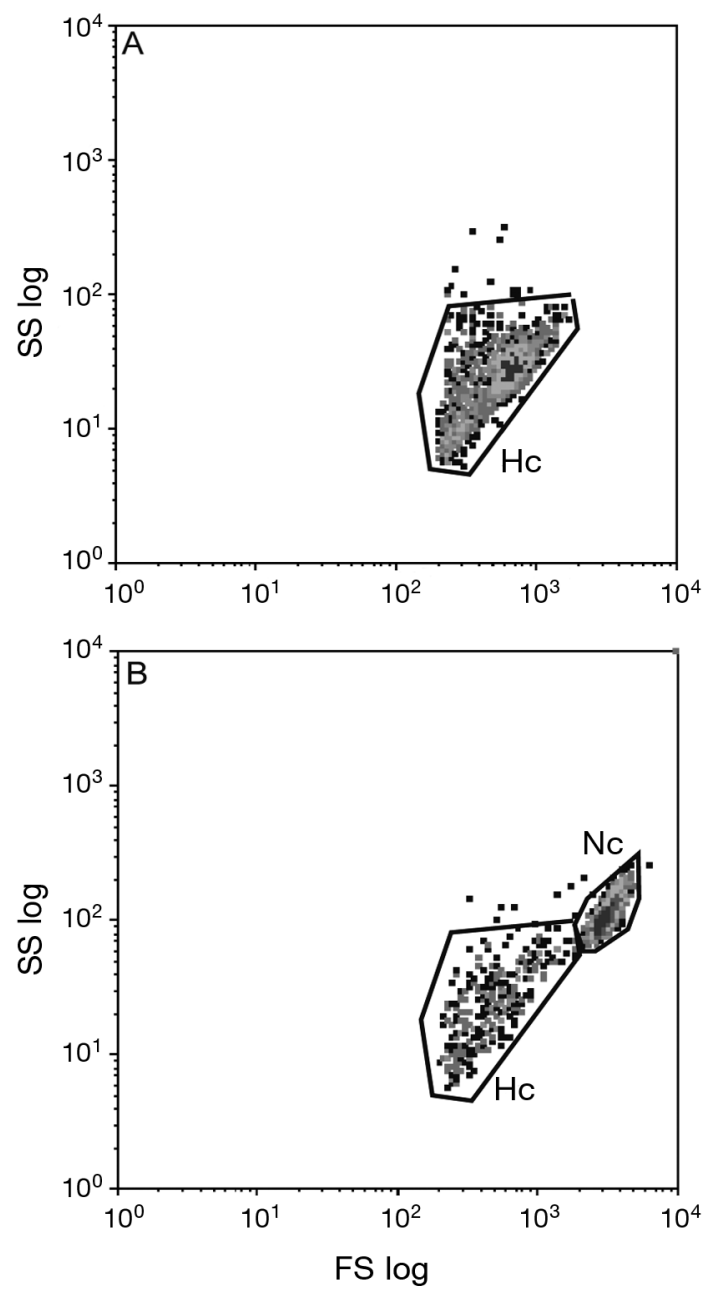

Fig. 2. Cerastoderma edule. Flow cytometry density plots of forward scatter (FS LOG) against side scatter (SS LOG) of haemolymph cells from (A) unaffected cockles (N0) and (B) moderate to highly affected cockles (N2+N3). The size (FS) and cell complexity (SS) parameters allow for the differentiation of unaffected haemocytes (Hc) from disseminated neoplasia-affected neoplastic cells (Nc)

cockles. The distribution of cells in populations according to the lysosome biovolume was significantly associated with the DN severity category. Categories with more severe DN had higher percentages of cells with high lysosome biovolume and lower percentages with moderate lysosome biovolume. The percentage of cells with low lysosome biovolume was similar in the 3 severity categories (Fig. 5).

\section{Reactive oxygen intermediates}

Two populations of haemolymph cells were detected based on ROI production, a cell population with low ROI production $(0.3 \pm 0.0$ fluorescence units)

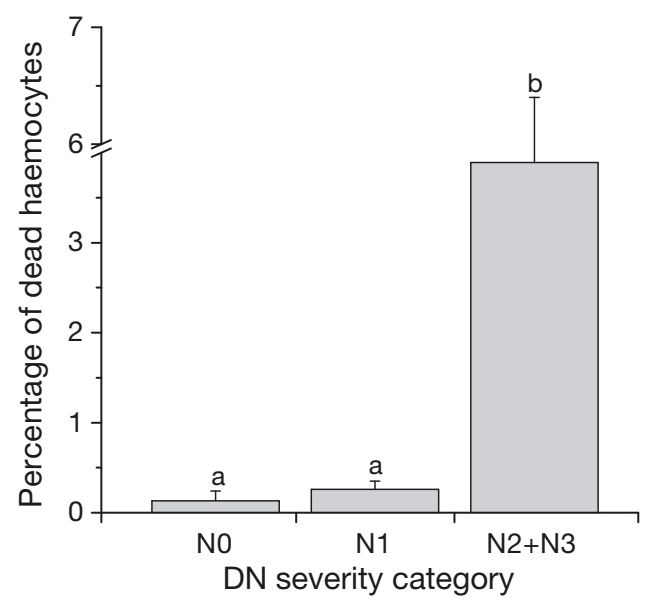

Fig. 3. Cerastoderma edule. Mean ( \pm SD) haemocyte mortality (\%) for each disseminated neoplasia (DN) severity category. DN severity categories N2 and N3 were grouped together because too few N3 cockles survived. Different lowercase letters indicate significant differences in the percentage of dead haemocytes, and different letters indicate significant differences in the percentage of dead neoplastic cells N0: cockles unaffected by $\mathrm{DN}_{i} \mathrm{~N} 1$ : cockles with low severity DN (<15\% neoplastic cells); N2: cockles with moderate severity DN (15 to $75 \%$ neoplastic cells); N3: cockles with high severity $\mathrm{DN}$ ( $>75 \%$ cells)

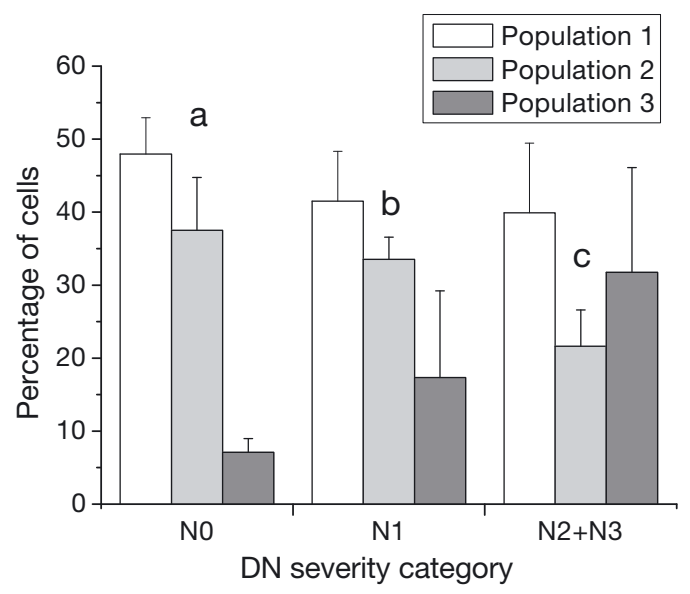

Fig. 4. Cerastoderma edule. Mean $( \pm \mathrm{SD})$ percentage of haemolymph cells for each disseminated neoplasia (DN) severity category divided into populations according to non-specific esterase activity level. Cells in Population 1 had no or low non-specific esterase activity, Population 2 medium and Population 3 high. Different letters indicate significant differences in the percentage of cells in each population between DN severity categories. See Fig. 3 legend for details of DN severity categories

containing cells corresponding to the size and inner complexity of haemocytes, and another with high production (1.5 \pm 0.3 fluorescence units) containing cells corresponding to the size and inner complexity of neoplastic cells. The percentage of cells with high 


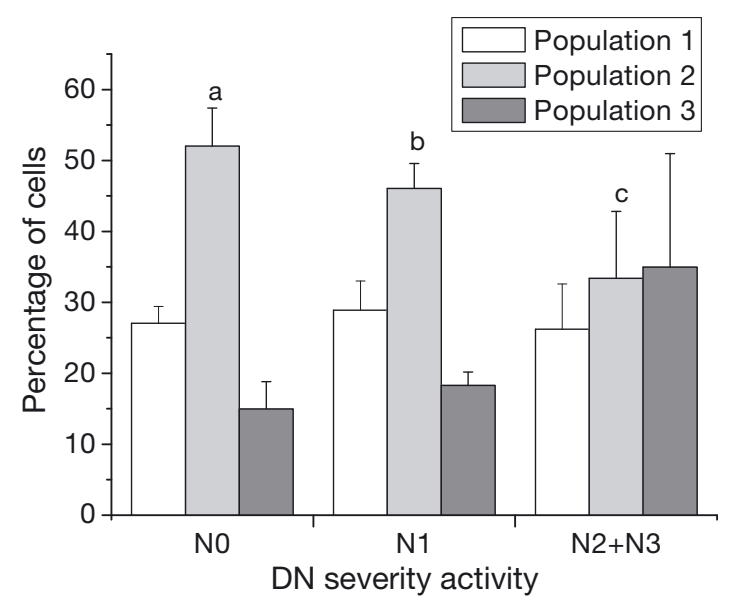

Fig. 5. Cerastoderma edule. Mean $( \pm \mathrm{SD})$ percentage of haemolymph cells for each disseminated neoplasia (DN) severity category divided into populations according to lysosome level detected. Cells in Population 1 had no or low lysosome biovolume, Population 2 medium and Population 3 high. Different letters indicate significant differences in the percentage of cells in each population between DN severity categories. See Fig. 3 legend for details of DN severity categories

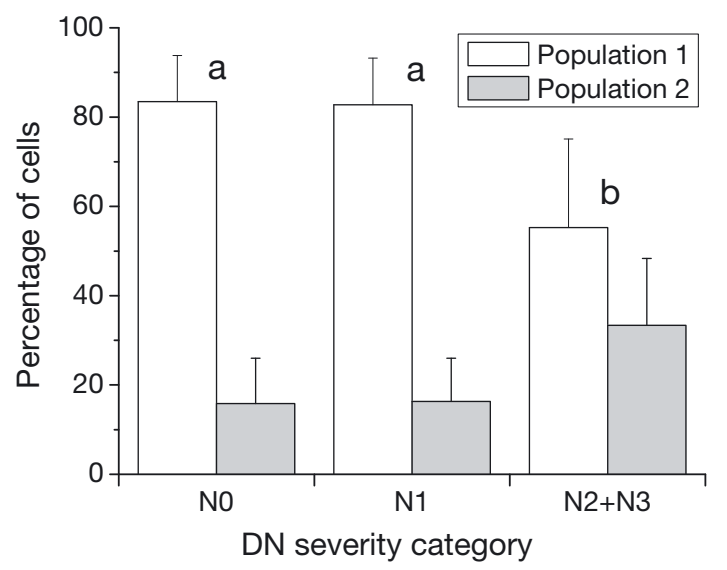

Fig. 6. Cerastoderma edule. Mean $( \pm \mathrm{SD})$ percentage of haemolymph cells for each disseminated neoplasia (DN) severity category divided into populations according to ROI production. Cells in Population 1 had low ROI production and Population 2 high. Different letters indicate significant differences in the percentage of cells in each population between DN severity categories. See Fig. 3 legend for details of DN severity categories

ROI production in N1 cockles was similar to that in N0 animals, but it was significantly higher in N2+N3 cockles. In addition, the percentage of cells with low ROI production in N1 cockles was similar to that in $\mathrm{N} 0$ animals, but it was significantly higher in N2+N3 (Fig. 6).

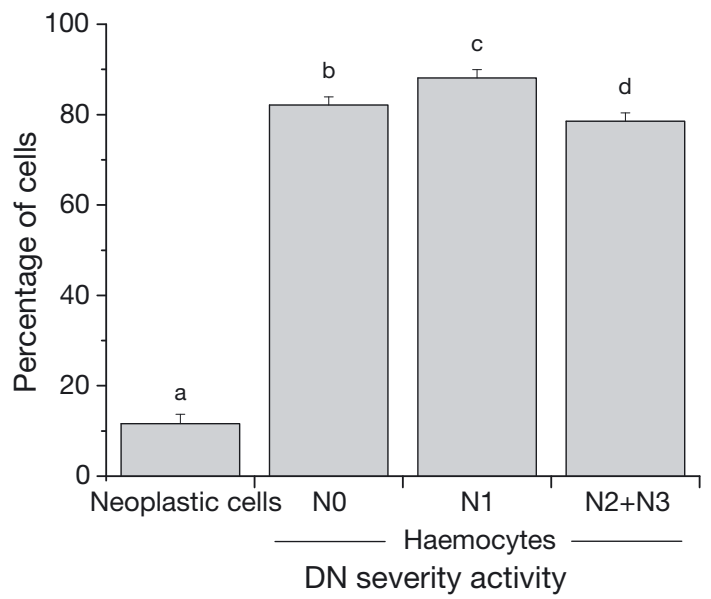

Fig. 7. Cerastoderma edule. Mean ( \pm SD) percentage of phagocytosing neoplastic cells after grouping the haemolymph pools from disseminated neoplasia (DN)-affected cockles (N1, N2 + N3 categories) and phagocytosing haemocytes from all DN severity categories. Different letters indicate significant differences. See Fig. 3 legend for details of DN severity categories

\section{Phagocytosis}

The phagocytic activity of haemolymph cells significantly decreased with increasing DN severity. The mean $( \pm \mathrm{SD})$ percentage of cells that had phagocytosed at least 3 particles was $82.14 \pm 1.77,79.24 \pm 1.82$, and $60.71 \pm 1.87$ for N0, N1 and N2+N3 DN severity categories, respectively. Phagocytosis activity was higher for haemocytes than for neoplastic cells (Fig. 7). A small portion of neoplastic cells showed phagocytic activity $(11.62 \pm 2.1 \%)$ but only phagocytosed up to 4 fluorescent beads, whereas haemocytes internalised up to 9 . The percentage of phagocytosing haemocytes was higher in N1 cockles $(88.12 \pm 1.82 \%)$ than in N0 cockles $(82.14 \pm 1.77 \%)$ and decreased further in $\mathrm{N} 2+\mathrm{N} 3$ cockles $(78.54 \pm 1.85 \%)$.

\section{Cytoplasmic-free $\mathrm{Ca}^{2+}$}

Two populations of cells were detected based on their content of cytoplasmic free $\mathrm{Ca}^{2+}$ : those cells with low (9.6 \pm 1.6 fluorescence units) and high content (108.5 \pm 8.8 fluorescence units), respectively. In this case there was no relationship between $\mathrm{Ca}^{2+}$ content and cell type based on size or complexity. Classification of cells into the 2 populations of cytoplasmic-free $\mathrm{Ca}^{2+}$ content was significantly dependent on DN severity. Differences were significant between DN-affected cockles and unaffected ones but were not significant between $\mathrm{N} 1$ and $\mathrm{N} 2+\mathrm{N} 3$ cockles (Fig. 8). 


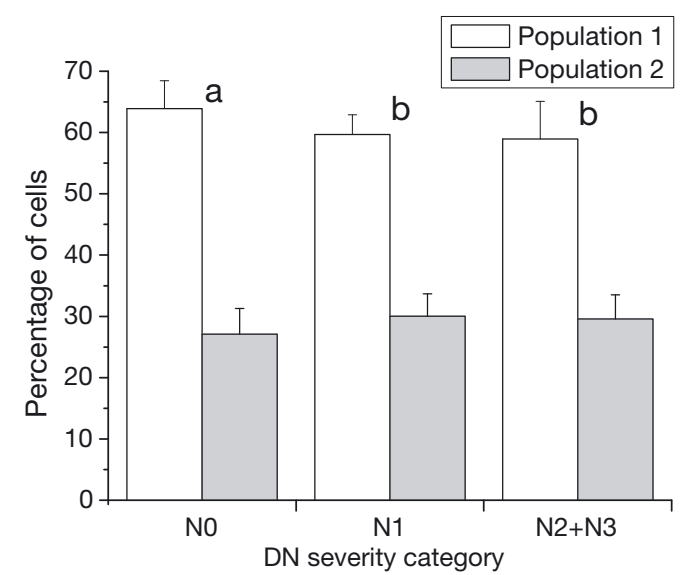

Fig. 8. Cerastoderma edule. Mean $( \pm$ SD) percentage of haemolymph cells for each disseminated neoplasia (DN) severity category divided into populations according to cytoplasmic-free $\mathrm{Ca}^{2+}$ content. Cells in Population 1 had low cytoplasmic-free $\mathrm{Ca}^{2+}$ content, and Population 2 high. Different letters indicate significant differences in the percentage of cells in each population between DN severity categories. See

Fig. 3 legend for details of DN severity categories

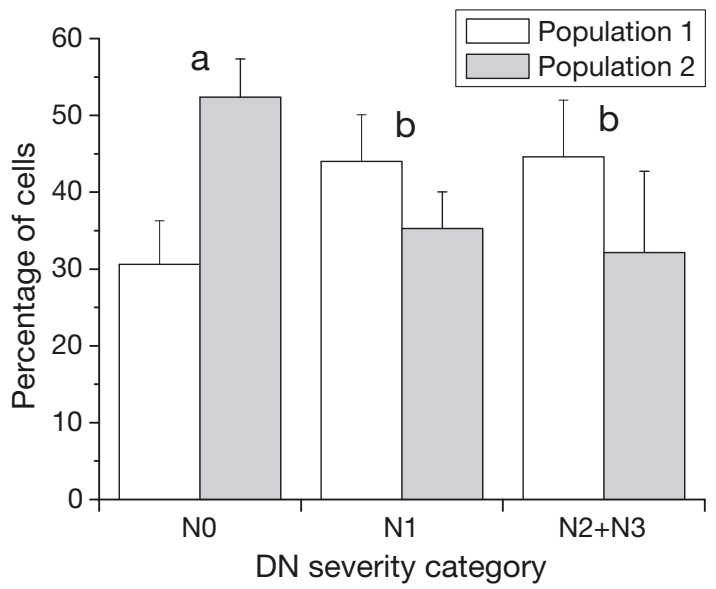

Fig. 9. Cerastoderma edule. Mean $( \pm \mathrm{SD}$ ) percentage of haemolymph cells for each disseminated neoplasia (DN) severity category divided into populations according to actin content. Cells in Population 1 had low actin content and Population 2 high. Different letters indicate significant differences in the percentage of cells in each population between DN severity categories. See Fig. 3 legend for details of DN severity categories

\section{Actin}

Cell types based on size and complexity were not distinguished due to the effects of the fixative used for this analysis. Two populations of cells were detected based on their actin content, those cells with low $(0.7 \pm$ 0.1 fluorescence units) and high content $(9.8 \pm 1.2$ fluorescence units), respectively. The actin content in cells was significantly associated with DN severity. The percentage of cells with high actin content was significantly lower in cockles affected by DN than in unaffected cockles, but no significant difference was detected between N1 and N2+N3 cockles (Fig. 9).

\section{DISCUSSION}

Histological sections, haemolymph cell monolayers, TEM and flow cytometry analyses allowed us to differentiate neoplastic cells occurring in the haemolymph of diseased cockles from normal cockle haemocytes. The ultrastructural characteristics of the neoplastic cells observed in the Galician diseased cockles closely resembled those of neoplastic cells from Cerastoderma edule from Brittany (Poder \& Auffet 1986) and Ireland (Collins 1998). Moreover, the presence of large nuclei, hypertrophied mitochondria and atypical Golgi complexes correspond to the ultrastructure features of neoplastic cells described from Macoma balthica (Farley 1976, Smolarz et al. 2006), Mya arenaria (Brown et al. 1977) and Mytilus edulis (Mix et al. 1979, Green \& Alderman 1983, Rasmussen 1986) affected by DN. The abundance of mitochondria in neoplastic cells could be related to the high quantity of energy required for cell division (Smolarz et al. 2006). Moreover, nucleolus hypertrophy could be a sign of high transcription activity that would be associated with protein synthesis related to the increased mitotic and metabolic activity. Some differences in DN cell morphology among bivalve mollusc species have been reported. Neoplastic cells of Mytilus sp. and Ostrea edulis showed morphological similarities with hyalinocytes (Mix 1983, Balouet et al. 1986), whereas those of $M$. arenaria resembled granulocytes because of the presence of granules in the cytoplasm (Yevich \& Barszcz, 1977). In our study, the lysosome biovolume and non-specific esterase activities observed in the neoplastic cells would set these cells closer to granulocytes than hyalinocytes. However, TEM examination of cockle neoplastic cells did not show the presence of electrondense granules that characterise bivalve granulocytes, although numerous electron-lucent vesicles were observed. The ultrastructural features of normal haemocytes are not discussed here (see 'Results') because the samples in the present study were not found to differ markedly from the description of cockle haemocyte types in Russell-Pinto et al. (1994).

These results demonstrated a significant association between DN severity and the values of each studied haemolymph cell parameter. Furthermore, haemocytes and neoplastic cells were mostly allocated into different cell populations based on fluorescence intensity in flow cytometry analyses of cell mortality, non-specific 
esterases, lysosome biovolume, ROI production and phagocytic activity, but they were not discriminated by cytoplasmic free $\mathrm{Ca}^{2+}$ and actin contents.

Neoplastic cells showed lower mortality than haemocytes in all intensities of DN. The higher haemocyte mortality in diseased cockles could be caused by toxic metabolites released by neoplastic cells. Serum proteins from soft shell clams Mya arenaria affected by DN had a cytotoxic effect when injected in healthy individuals (Sunila \& Dungan 1992). Isolated serum from diseased clams increased soft shell clam mortality even when the disease was not transmitted. Neoplasiaspecific proteins were described in the sera from diseased soft shell clams (Sunila \& Dungan 1992). In addition, oxygen tension in the haemolymph of neoplastic $M$. arenaria has been reported to decrease with the progression of neoplastic disease, which could be due to the high metabolic activity related to maintaining the high division rate of neoplastic cells (Sunila 1991). Thus, haemocyte mortality in neoplastic cockles could also be attributed to insufficient haemolymph oxygenation.

Neoplastic cells showed much lower phagocytosis activity than haemocytes. These results are similar to those obtained in studies of other neoplastic bivalves, Mytilus trossulus (Noël, 1992), M. edulis (Galimany \& Sunila 2008) and Mya arenaria (Beckmann et al. 1992, Potts 1993, Walker \& Böttger 2008). Furthermore, a significant decrease in the phagocytic activity of haemocytes was detected in moderate to highly diseased cockles, which is consistent with a decrease in the proportion of granulocytes observed in those cockles. Despite the increased beads:haemocytes ratio because neoplastic cells were not phagocytically active. The higher haemocyte mortality and the lower haemocyte phagocytic ability suggest that immune capacities can be impaired in $\mathrm{DN}$-affected cockles.

The reduced phagocytic ability of neoplastic cells with regard to haemocytes contrasts with the higher lysosome biovolume, non-specific esterase activities and ROI production of the former. Various lysosomal enzymes, such as acid phosphatase, $\beta$-glucuronidase in Mya arenaria (Beckmann et al. 1992) and cystine arylamidase in Mytilus trossulus (Noël 1992), have been detected at higher concentrations in DN-affected molluscs than in healthy ones. The high lysosome biovolume detected in neoplastic cells suggests that many of the vesicles observed with TEM are lysosomes, although this result requires further confirmation.

These results show that a significant increase in ROI production is associated with advanced (moderate and high) stages of DN. Previous information on ROI production by mollusc neoplastic cells is scarce. Galimany \& Sunila (2008) did not observe significant differences in ROI production between DN-affected and unaf- fected mussels. However, human cancer cells exhibit increased intrinsic oxidative stress (Schumacker 2006). In molluscs, ROIs are involved in host defence but also act as secondary messengers to regulate array processes such as enzymatic activities, $\mathrm{Ca}^{2+}$ signalling and p53 pathways (Gómez-Lázaro et al. 2004), which could contribute to explaining the high ROI levels in neoplastic cells.

Haemolymph cells in DN-affected cockles showed higher levels of cytoplasmic-free $\mathrm{Ca}^{2+}$ than those in healthy cockles, although these differences were not as marked as those in other cell parameters. $\mathrm{Ca}^{2+}$ is a key messenger involved in the regulation of different cell processes including cell cycling, gene transcription and apoptosis, so that even subtle changes in $\mathrm{Ca}^{2+}$ signalling may promote pathways important to cancer growth, survival and metastasis (Roderick \& Cook 2008). Cytoplasmic-free $\mathrm{Ca}^{2+}$ and actin filaments are involved in dynamic processes of cellular functioning, such as adhesion, membrane dynamics, and mobility, and contractile ones, such as cell division (Hennessey et al. 1993, Ballarin et al. 1997). The limited phagocytosis ability of neoplastic cells could be due to changes in cytoplasmic-free $\mathrm{Ca}^{2+}$ and actin levels. Actin content in haemolymph cells from DN-affected cockles was lower than that in unaffected cockles. However, actin filaments are involved in the contractile ring that contributes to cytokinesis in the last stage of cell division. Therefore, actin is important to maintain the high division rate of neoplastic cells. Moore et al. (1992) found significant differences in the cytoskeletal architecture between neoplastic cells and haemocytes from Mya arenaria, including in the overall amount of actin (lower in neoplastic cells) and the organisation of actin filaments. Cytoskeleton alteration may represent a common pathway of cellular damage caused by reactive oxygen species (Healy et al. 1992). The cytoskeleton is sensitive to ROIs and oxidative stress due to the presence of thiol groups located on the actin microfilaments, which are sensitive to oxidation (Möller et al. 2005).

Acknowledgements. The authors thank M. Angueira, E. Penas and I. Meléndez for technical assistance. This study was supported by funds from the Autonomous Galician Goverment (Xunta de Galicia) through the project PGIDIT06PXIB501132PR. S.D. was supported by a scholarship from the Consellería do Mar da Xunta de Galicia. The helpful suggestions of 3 anonymous reviewers are gratefully acknowledged.

\section{LITERATURE CITED}

Aton E, Renault T, Gagnaire B, Thomas-Guyon H, Cognard C, Imbert N (2006) A flow cytometric approach to study intracellular-free $\mathrm{Ca}^{2+}$ in Crassostrea gigas haemocytes. Fish Shellfish Immunol 20:493-502 
Ballarin L, Cima F, Sabbadin A (1997) Calcium homeostasis and yeast phagocytosis in hemocytes of the colonial ascidian Botryllus shlosseri. Comp Biochem Physiol 118: 153-158

Balouet G, Poder M (1985) Current status of parasitic and neoplastic diseases of shellfish: a review. In: Ellis AW (ed) Fish and shellfish pathology. Academic Press, London, p 371-380

Balouet G, Poder M, Cahour A, Auffret M (1986) Proliferative hemocytic condition in European flat oysters (Ostrea edulis) from Breton coasts: a 6 -year survey. J Invertebr Pathol 48:208-215

Barber BJ (2004) Neoplastic diseases of commercially important marine bivalves. Aquat Living Resour 17:449-466

Beckmann N, Morse MP, Moore CM (1992) Comparative study of phagocytosis in normal and diseased hemocytes of the bivalve mollusc Mya arenaria. J Invertebr Pathol 59: 124-132

Brown RS, Wolke RE, Saila SB, Brown CW (1977) Prevalence of neoplasia in 10 New England populations of the softshell clam (Mya arenaria). Ann NY Acad Sci 298:522-534

Carballal MJ, Iglesias D, Santamarina J, Ferro-Soto B, Villalba A (2001) Parasites and pathologic conditions of the cockle Cerastoderma edule populations of the coast of Galicia (NW Spain). J Invertebr Pathol 78:87-97

Cheng TC (1981) Bivalves. In: Ratcliffe NA, Rowly AF (eds) Invertebrate blood cells, Vol 1. Academic Press, London, p 233-300

Collins C (1998) Studies on a neoplasm of the cockle, Cerastoderma edule (Linnaeus). PhD thesis, University College Cork

> Díaz S, Cao A, Villalba A, Carballal MJ (2010) Expression of mutant protein p53 and Hsp70 and Hsp90 chaperones in cockles Cerastoderma edule affected by neoplasia. Dis Aquat Org 90:215-222

Donaghy L, Hong H-K, Lambert C, Park H-S, Shim WJ, Choi K-S (2010) First characterisation of the populations and immune-related activities of hemocytes from two edible gastropod species, the disk abalone, Haliotis discus discus and the spiny top shell, Turbo cornutus. Fish Shellfish Immunol 28:87-97

Elston RA, Kent ML, Drum AS (1988) Progression, lethality and remission of hemic neoplasia in the bay mussel Mytilus edulis. Dis Aquat Org 4:135-142

Elston RA, Moore JD, Brooks K (1992) Disseminated neoplasia of bivalve molluscs. Rev Aquat Sci 6:405-466

Farley CA (1976) Proliferative disorders in bivalve molluscs. Mar Fish Rev 38:30-33

Fisher WS, Ford SE (1988) Flow cytometry: a tool for cell research in bivalve pathology. Spec Publ Am Fish Soc 18: 286-291

> Gagnaire B, Thomas-Guyon H, Renault T (2004) In vitro effects of cadmium and mercury on Pacifc oyster, Crassostrea gigas (Thunberg), haemocytes. Fish Shellfish Immunol 16:501-512

Gagnaire B, Thomas-Guyon H, Burgeot Th, Renault T (2006) Pollutant effects on Pacific oyster, Crassostrea gigas (Thunberg), hemocytes: screening of 23 molecules using flow cytometry. Cell Biol Toxicol 22:1-14

Gagnaire B, Duchemin M, Auffret M, Thomas-Guyon H, Renault T (2008) Comparison of hemocyte parameters in the pericardial cavity and the adductor muscle sinus in the Pacific oyster, Crassostrea gigas using two types of flow cytometers. Aquat Living Resour 21:39-43

Galimany E, Sunila I (2008) Several cases of disseminated neoplasia in mussels Mytilus edulis (L.) in western Long Island Sound. J Shellfish Res 27:1201-1207
Goedken M, Morsey B, Sunila I, de Guise S (2005) Immunomodulation of Crassostrea gigas and Crassostrea virginica cellular defense mechanisms by Perkinsus marinus. J Shellfish Res 24:487-496

Gómez-Lázaro M, Fernández-Gómez FJ, Jordán J (2004) La proteína p53 en procesos neurodegenerativos en sus 25 años de historia. Rev Neurol 39:243-250

Green M, Alderman DJ (1983) Neoplasia in Mytilus edulis L. from United Kingdom waters. Aquaculture 30:1-10

Healy AM, Mariethoz E, Pizurki L, Polla BS (1992) Heat shock proteins in cellular defense mechanisms and immunity. Ann NY Acad Sci 663:319-329

Hennessey ES, Drummond DR, Sparrow JC (1993) Molecular genetics of actin function. Biochem J 282:657-671

Kent ML, Elston RA, Wilkinson MT, Drum AS (1989) Impaired defense mechanisms in bay mussels, Mytilus edulis, with hemic neoplasia. J Invertebr Pathol 53:378-386

> Lowe DM, Moore MN (1978) Cytology and quantitative cytochemistry of a proliferative atypical hemocytic condition in Mytilus edulis (Bivalvia, Mollusca). J Natl Cancer Inst 60: 1455-1459

Miosky DL, Smolowitz RM, Reinisch CL (1989) Leukemia cell specific protein of the bivalve mollusc Mya arenaria. J Invertebr Pathol 53:32-40

> Mix MC (1983) Haemic neoplasms of bay mussels, Mytilus edulis L., from Oregon: occurrence, prevalence, seasonality and histopathological progression. J Fish Dis 6: 239-248

> Mix M, Hawkes JW, Sparks AK (1979) Observations on the ultrastructure of large cells associated with putative neoplastic disorders of mussels, Mytilus edulis, from Yaquina Bay, Oregon. J Invertebr Pathol 34:41-56

Möller W, Brown DM, Kreyling WG, Stone V (2005) Ultrafine particles cause cytoskeletal dysfunctions in macrophages: role of intracellular calcium. Part Fibre Toxicol 2:7

Moore CA, Beckmann N, Morse MP (1992) Cytoskeletal structure of diseased and normal hemocytes of Mya arenaria. J Invertebr Pathol 60:141-147

> Morga B, Arzul I, Chollet B, Renault T (2009) Infection with the protozoan parasite Bonamia ostreae modifies in vitro haemocyte activities of flat oyster Ostrea edulis. Fish Shellfish Immunol 26:836-842

Noël D (1992) Etude des hémocytes et d'une néoplasie hémocytaire chez les moules Mytilus edulis et Mytilus trossulus (Mollusca, Bivalvia). PhD thesis, University of Bordeaux

Peters EC (1988) Recent investigations on the disseminated sarcomas of marine bivalve molluscs. Spec Publ Am Fish Soc 18:74-92

Poder M, Auffret M (1986) Sarcomatous lesion in the cockle Cerastoderma edule: I. Morphology and population survey in Brittany, France. Aquaculture 58:1-8

Potts MS (1993) Effects of hematopoietic neoplasia on physiological processes in the soft-shell clam, Mya arenaria (Linne.) PhD thesis, University of New Hampshire, Durham, NH

Rasmussen LPD (1986) Occurrence, prevalence and seasonality of neoplasia in the marine mussel Mytilus edulis from three sites in Denmark. Mar Biol 92:59-64

$>$ Roderick HL, Cook SJ (2008) $\mathrm{Ca}^{2+}$ signalling checkpoint in cancer: remodelling $\mathrm{Ca}^{2+}$ for cancer cell proliferation and survival. Nat Rev Cancer 8:361-375

Russell-Pinto F, Reimão R, de Sousa M (1994) Haemocytes in Cerastoderma edule (Mollusca, Bivalvia): distinct cell types engage in different responses to sheep erythrocytes. Fish Shellfish Immunol 4:383-397

Samain JF, Dégremont L, Soletchnik P, Haure J and others (2007) Genetically based resistance to summer mortality in 
the Pacific oyster (Crassostrea gigas) and its relationship with physiological, immunological characteristics and infection processes. Aquaculture 268:227-243

Schumacker PT (2006) Reactive oxygen species in cancer cells: live by the sword, die by the sword. Cancer Cell 10: 175-176

Shi G, Wu Y, Zhang J, Wu J (2003) Death decoy receptor TR6/DcR3 inhibits $\mathrm{T}$ cell chemotaxis in vitro and in vivo. J Immunol 171:3407-3414

Smolarz K, Renault T, Wolowicz M (2006) Ultrastructural study of neoplastic cells in Macoma balthica (Bivalvia) from the Gulf of Gdansk (Poland). J Invertebr Pathol 92: 79-84

Sunila I (1991) Respiration of sarcoma cells from the soft-shell clam Mya arenaria L. under various conditions. J Exp Mar Biol Ecol 150:19-29

Sunila I, Dungan CF (1992) Different proteins in the hemolymph sera from sarcomatous and healthy soft shell clams, Mya arenaria L. Comp Biochem Physiol B 102: 621-625

Tiscar PG, Mosca F (2004) Defense mechanisms in farmed

Editorial responsibility: Alex Hyatt, Geelong, Victoria, Australia marine molluscs. Vet Res Commun 28:57-62

Villalba A, Carballal MJ, López C (2001) Disseminated neoplasia and large foci indicating heavy haemocytic infiltration in cockles Cerastoderma edule from Galicia (NW Spain). Dis Aquat Org 46:213-216

> Walker CW, Böttger SA (2008) A naturally occurring with molecular connectivity to human diseases. Cell Cycle 7: 2286-2289

> White MK, Miosky D, Flessas DA, Reinish CL (1993) The expression of an adhesion-related protein by clam hemocytes. J Invertebr Pathol 61:253-259

Xue Q, Renault T, Chilmonczyk S (2001) Flow cytometric assessment of haemocyte sub-populations in the European flat oyster, Ostrea edulis, haemolymph. Fish Shellfish Immunol 11:557-567

Yakovleva NV, Samoilovich MP, Gorbushin AM (2001) The diversity of strategies of defense from pathogens in molluscs. J Evol Biochem Physiol 37:358-367

Yevich PP, Barszcz CA (1977) Neoplasia in soft-shell clams (Mya arenaria) collected from oil-impacted sites. Ann NY Acad Sci 298:409-426

Submitted: January 20, 2011; Accepted: June 20, 2011 Proofs received from author(s): August 29, 2011 